\title{
Quality Control of Trichogramma atopovirilia and Trichogramma pretiosum (Hym.: Trichogrammatidae) Adults Reared Under Laboratory Conditions
}

\author{
Marcus Alvarenga Soares ${ }^{*}$, Germano Leão Demolin Leite ${ }^{2}$, José Cola Zanuncio ${ }^{3}$, \\ Veríssimo Gibran Mendes de Sá ${ }^{4}$, Cleidson Soares Ferreira ${ }^{2}$, Silma Leite Rocha ${ }^{3}$, Evaldo \\ Martins Pires ${ }^{5}$ and José Eduardo Serrão ${ }^{6}$ \\ ${ }^{1}$ Faculdade de Ciências Agrárias; Universidade Federal dos Vales do Jequitinhonha e Mucuri; 39100-000; \\ Diamantina - MG - Brasil. ${ }^{2}$ Instituto de Ciências Agrárias; Universidade Federal de Minas Gerais; C. P.: 135; \\ 39404-006; Montes Claros - MG - Brasil. ${ }^{3}$ Departamento de Biologia Animal; Universidade Federal de Viçosa; \\ 36571-000; Viçosa - MG - Brasil . ${ }^{4}$ Faculdade de Engenharia; Universidade do Estado de Minas Gerais; $35930-$ \\ 000; João Monlevade -MG - Brasil. ${ }^{5}$ Instituto de Ciências Naturais, Humanas e Sociais; Universidade Federal de \\ Mato Grosso; 78557-000, Sinop - MT - Brasil. ${ }^{6}$ Departamento de Biologia Geral; Universidade Federal de Viçosa; \\ 36571-000; Viçosa - MG - Brasil
}

\begin{abstract}
The objective of this work was to assess the flight capacity, parasitism and emergence of Trichogramma atopovirilia and two strains of $\mathrm{T}$. pretiosum (Hymenoptera: Trichogrammatidae) (L1 and L2). The flight capacity of these species was assessed in test units consisting of a plastic PVC cylinder with a rigid transparent plastic circle on the upper part and an extruded polystyrene disk closing its bottom. A tube was placed in each test unit containing a card with 300 Anagasta kuehniella (Lepidoptera: Pyralidae) eggs parasitised by Trichogramma. These cards were assessed to determine the parasitism rate and adult emergence of these natural enemies. T. atopovirilia and $\mathrm{T}$. pretiosum $L 1$ presented adequate flight capacity and parasitism, in addition to high percentages of adults emerged.
\end{abstract}

Key words: biological control, flight, parasitism, quality control, emergence

\section{INTRODUCTION}

The caterpillars of Spodoptera frugiperda (J.E. Smith) and Helicoverpa zea (Boddie) (Lepidoptera: Noctuidae) have great economic importance in corn crops in Brazil (Zanuncio et al. 2008; Rodriguez-del-Bosque et al. 2010; Barrera et al. 2011). These pests are generally controlled with insecticides that can cause negative impacts, such as pest resistance and environmental unbalance (Soares et al. 2009; Barrera et al. 2011). However, a range of natural enemies can perform the biological control of these pests, such as Braconidae, Ichneumonidae, Eulophidae and Trichogrammatidae species parasitising eggs or larvae of S. frugiperda (Hoballah et al. 2004; Neto et al. 2004; Neto et al. 2005).

Biological control has been intensified, especially for $S$. frugiperda and $H$. zea, with releases of Trichogramma atopovirilia (Oatman and Platner) and T. pretiosum (Riley) (Hymenoptera: Trichogrammatidae), frequent parasitoids of eggs of these pests (Parra and Zucchi 2004). T. pretiosum is very common in many cultures,

*Author for correspondence: marcusasoares@yahoo.com.br 
including avocado, cucumber and tomato (Miranda et al. 1998; Goring et al. 2003). These natural enemies can be easily multiplied with highly efficient and cheap methodologies (Oliveira et al. 2000; Oztemiz and Kornosor 2007). The Trichogramma species are released in the field after several generations of mass rearing in the laboratory that can reduce their biological characteristics (Prasad et al. 1999; Pratissoli et al. 2004).

Flight capacity is important for parasitoid dispersion and this attribute can vary during the colonization process or mass rearing. This was determined for two strains of $T$. brassicae (Bezdenko) (Hymenoptera: Trichogrammatidae) after two and 39 generations in the laboratory on Ephestia kuehniella (Zeller) (Lepidoptera: Pyralidae) eggs (Dutton and Bigler 1995) and for T. sibericum (Sorkina) (Hymenoptera: Trichogrammatidae) reared at different temperatures $\left(16,21\right.$ and $\left.26^{\circ} \mathrm{C}\right)$ on eggs of its natural host Rhopobata naevana (Hubner) (Lepidoptera: Tortricidae) (Prasad et al. 1999). The flight capacity of five Trichogramma species collected in eucalypt plantations was determined and T. maxacalii (Voegelé and Pointel) (Hymenoptera: Trichogrammatidae) showed the best flying ability (Soares et al. 2007).

Furthermore, rearing for successive generations can affect the ability to locate and to parasitize and parasitoid emergence of Trichogramma spp. (Pratissoli et al. 2004). The flight capacity, parasitism and emergence of Trichogramma spp. can differ depending on the species and/or strains of these parasitoids. Thus, these biological parameters may be used to select the species or strains as a simple, fast and cheap method of quality control of these natural enemies (Dutton and Bigler 1995; Prasad et al. 1999; Pratissoli et al. 2005a; Soares et al. 2007).

The objective of this work was to compare the flight capacity, parasitism and emergence of $T$. atopovirilia and $T$. pretiosum strains L1 and L2 adults reared on Anagasta kuehniella (Zeller) (Lepidoptera: Pyralidae) eggs.

\section{MATERIALS AND METHODS}

Trichogramma atopovirilia and T. pretiosum strain L1 were obtained from the rearing facility of EMBRAPA National Research Center for Corn and Sorghum-CNPMS in the municipality of Sete
Lagoas, Minas Gerais State, Brazil. Strain L2 was collected from the corn crops in the municipality of Montes Claros, Minas Gerais State, Brazil. The parasitoids were reared and multiplied at $25 \pm 2{ }^{\circ} \mathrm{C}$ and 12-h light period.

Eggs from the alternative host A. kuehniella, obtained according to the technique of Parra (1997) were fixed with Arabic gum diluted to $30 \%$ on $7.20 \times 0.7 \mathrm{~cm}$ pieces of white card, placed for 60 minutes under an ultraviolet lamp at $25 \mathrm{~cm}$ high and used to maintain the parasitoids in the laboratory (Stein and Parra 1987). Each card, with 300 eggs of this host, was placed in a test tube $(12.0 \times 2.0 \mathrm{~cm})$ with 30 newly emerged telitoc females of one of the Trichogramma species or strains (Stouthamer et al. 1993), at the proportion of one parasitoid for 10 eggs. The parasitism was permitted for five hours (Pratissoli and Parra 2000; Soares et al. 2007). A drop of pure honey was placed in each test tube to feed the parasitoids (Lundgren and Heimpel 2003).

The flight capacity of the Trichogramma species and strains was assessed in test units (Soares et al. 2007), consisting of a $18 \mathrm{~cm}$ high, $11 \mathrm{~cm}$ diameter PVC cylinder with its inside painted with black latex paint. The bottom of the cylinders was closed with black flexible plastic (larger in size than the tube diameter) firmly fitted by an extruded polystyrene disk that was approximately $1 \mathrm{~cm}$ thick and with the same diameter as the tube. The excess at the edges of the plastic on the outside of the tube after fitting were attached to it with elastic, for better sealing and to prevent parasitoid to escape.

Each card with 300 A. kuehniella eggs, parasitized by Trichogramma and near the adult emergence of these parasitoids was placed inside a test tube (7.5 $\mathrm{x} 1.0 \mathrm{~cm}$ ) and fixed at the center of the bottom part of the test unit (extruded polystyrene disk) with adhesive tape (Prezotti et al. 2002). A ring of gum was applied to the inside wall of the cylinder at 4 $\mathrm{cm}$ from the lower end, as a barrier to parasitoid walking. A circle of rigid, transparent plastic, of a larger diameter than that of the PVC and brushed with glue $24 \mathrm{~h}$ prior to the beginning of the experiment, was placed on the top of the cylinder, as a trap for parasitoids in flight.

Four replications were carried out per Trichogramma species and strains at $25 \pm 2{ }^{\circ} \mathrm{C}$ and $24 \mathrm{~h}$ light period. The plots were randomly distributed on a counter under a continuous light source from the date of mounting (Prezotti et al. 2002). The parasitoids were kept in the test unit 
for three days after the start of their emergence and then frozen.

The numbers of parasitoids caught in the glue ring "walkers" on the plastic circle "flyers" and on the bottom "non-flyers" were recorded by direct counting with a hand magnifying glass to calculate the percentage of each group in relation to the total adults emerged. The cards with parasitized $A$. kuehniella eggs were removed from the test tube after the death of the Trichogramma adults and assessed at three pre-determined points (superior, mean and inferior parts of the cards) under a magnifying glass (40X) to determine the number of eggs parasitized (Soares et al. 2007). These data were obtained by counting the number of blackened A. kuehniella eggs.

The emergence rate was calculated by counting the number of eggs with Trichogramma emergence, observing the opening on the corium of the host $A$. kuehniella eggs. The data were transformed to arcosen of $\mathrm{x}$ and submitted to analysis of variance and the means compared by the Scott-Knott test (Scott and Knott 1974) at 5\% probability with the SAEG statistic program (Gomes 1985). Results were presented in percentage.

\section{RESULTS AND DISCUSSION}

The Trichogramma species and the strains presented similar flight capacity and both species had low percentage of individuals caught in the glue ring (walkers). The number of non-flyer individuals was low in all the treatments (Fig. 1).

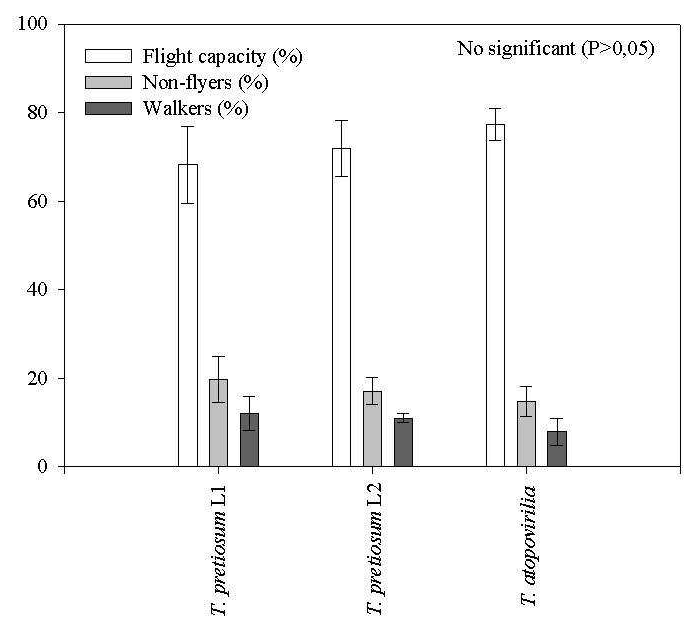

Figure 1 - Mean \pm standard error of the percentage of flyers, non-flyers and walkers adults of Trichogramma pretiosum L1, Trichogramma pretiosum L2 and Trichogramma atopovirilia. Municipality of Montes Claros, Minas Gerais State, Brasil.

The similar flight capacity of T. atopovirilia and $T$. pretiosum indicated that both the species could be released in the field but this might vary with the biological and behavioral characteristics and/or the mass rearing techniques of strains or species of these natural enemies. This was due to the fact that the percentage of adults with deformed wings and lower flight aptitude could increase in the laboratory (Prezotti et al. 2002). In this situation, the flight test performed showed sensitivity to detect the percentage of individuals flying reared under the laboratory conditions. Prezotti et al. (2002) observed that all the individuals who reached the top of the test unit had wings fully expanded, indicating that the parasitoid reached the site flying and not walking.

Furthermore, the environmental temperature can affect Trichogramma flight capacity, as reported for $T$. sibericum that presented variation in the proportion of adults with highest flight capacity $(51.74 \pm 2.3 \%)$ at $26^{\circ} \mathrm{C}$ and the lowest $(1.57 \pm$ $0.5 \%)$ at $16^{\circ} \mathrm{C}$ (Prasad et al. 1999). T. pretiosum, reared on A. kuehniella eggs presented $81.1 \pm$ $4.20 \%$ individuals with flight capacity (Prezotti et al. 2002) while two $T$. brassicae strains had 72 and $61 \%$ individuals with flight capacity, with the 
same host (Dutton and Bigler 1995). T. acacioi (Brun), T. bruni (Nagaraja), T. demoraesi (Nagaraja), T. maxacalii (Voegelé and Pointel) and T. soaresi (Nagaraja) (Hymenoptera: Trichogrammatidae) had respectively 39, 50, 45,
57 and $46 \%$ of flying individuals when reared with A. kuehniella eggs (Soares et al. 2007).

The $T$. pretiosum L2 strain presented lower parasitism rate on A. kuehniella eggs, than the L1 and T. atopovirilia (Fig. 2).
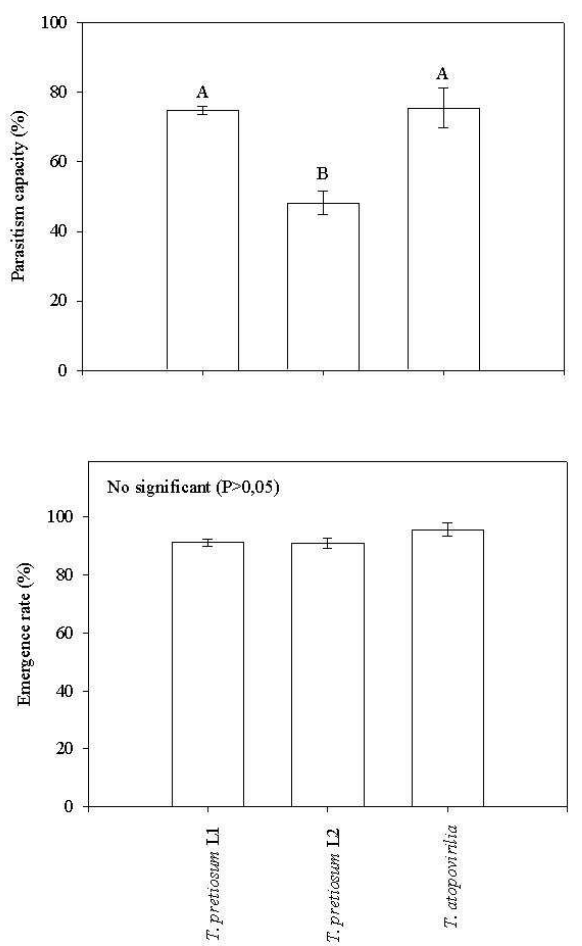

Figure 2 - Mean \pm standard error of the percentage of eggs parasitized and of emergence rate of Trichogramma pretiosum L1 and L2 and Trichogramma atopovirilia. Municipality of Montes Claros, Minas Gerais State, Brasil. Bars followed by the same letter do not differ by the Scott-Knott test at $5 \%$ probability.

The greater parasitism rates of T. atopovirilia and T. pretiosum strain L1 could be related to the fact that L2 strain was recently collected and it was still in an adaptation process to laboratory conditions and to the host used. Thus, the greater parasitism of $T$. atopovirilia and $T$. pretiosum $\mathrm{L} 1$ could be explained by the experience of the females after a certain number of generations parasitizing the alternative host, as reported for the associative learning of $T$. atopovirilia and $T$. pretiosum on $S$. frugiperda eggs after several generations (Bezerra and Parra 2003). This also indicated that the Trichogramma species could increase their preference for a determined host and $T$. pretiosum L2 might, after certain period of mass rearing, increase its parasitism rate on $A$. kuehniella eggs and thus to present similar results of the other treatments. Trichogramma parasitism rate also varied with physical and chemical barriers and by the type and characteristics of host eggs such as their size, hardness, scales and cairomones (Bezerra and Parra 2004). Temperature could also affect the parasitism capacity, with many Trichogramma species presenting maximum fertility between 21 and $30^{\circ} \mathrm{C}$ that decreased in extreme temperatures (Prasad et al. 1999; da Fonseca et al. 2005; Zago et al. 2007). Life tables for $T$. pretiosum and $T$. atopovirilia reared with $H$. zea eggs showed higher specific fertility for the first species with all temperatures tested. The ideal temperature to rear $T$. pretiosum was $28^{\circ} \mathrm{C}$ with higher number of females produced per female of this parasitoid $(\Sigma m x=104.48)$. On the other hand, $T$. atopovirilia had better 
development at $23^{\circ} \mathrm{C}(\Sigma m x=42.16)$ and lower tolerance to high temperatures without development at $33^{\circ} \mathrm{C}$ (Navarro and Marcano 2000). Food absence (carbohydrates) could also affect the parasitism, such as reported for $T$. pretiosum (Bai et al. 1992) and T. maxacalii (Oliveira et al. 2003).

The two strains of $T$. pretiosum and $T$. atopovirilia presented adequate adult emergence rate (Fig. 2). The emergence rates showed higher values than those of T. pretiosum and T. exiguum (Pinter and Platner) (Hymenoptera: Trichogrammatidae), both with $86 \%$ of emergence at $28^{\circ} \mathrm{C}$ from Plutella xylostella (Linnaeus) (Lepidoptera: Plutellidae) eggs (Pereira et al. 2004) and $T$. pretiosum $(88.5 \%)$ from $S$. cerealella eggs at $30^{\circ} \mathrm{C}$ (Inoue and Parra 1998). The emergence rate of Trichogramma adults can also vary with the size and quality of the host egg, number of parasitoids that develop per egg, development period in host eggs and temperature (Doyon and Boivin 2005; Pratissoli et al. 2005a). Younger and larger diameter eggs may favor parasitoid development because of the greater use of the food reserves with a single parasitoid developing per egg, due to the lack of competition. However, the number of adults that develop per egg varies with the availability of host eggs for the parasitoid that increases as the egg availability decreases (Hohmann and Luck 2004). The biological control with Trichogramma spp. should use species with higher emergence rates from the host eggs even in adverse conditions because they present better performance for field releases and to colonize the area in biological control programs.

Species with high flight capacity and emergence rates can disperse quicker in the field to find the host and to produce high progeny numbers in shorter periods of time. Trichogramma spp. should present higher variability of these biological characteristics in the field due to environmental factors such as temperature, light and/or food (Lundgren and Heimpel 2003; Pratissoli et al. 2005a; Pratissoli et al. 2005b; Ulrichs and Mewis 2004). On the other hand, species of this genus with better performance in the laboratory could repeat it in the field. These studies can choose adequate species or strains of Trichogramma to be released for inundative biological control.

\section{CONCLUSIONS}

1. T. atopovirilia and T. pretiosum strain L1 presented adequate flight capacity, parasitism and high percentages of adults emerged in the laboratory.

2. T. atopovirilia and T. pretiosum strain L1 were suitable for multiplication and release in the field for biological control.

\section{ACKNOWLEDGMENTS}

The authors thank professor George W.G. de Morais for the donation of the Anagasta kuehniella, the National Research Center for Corn and Sorghum EMBRAPA-CNPMS for the donation of the Trichogramma species, Dra. Ranyse Barbosa Querino, EMBRAPA, Teresina, PI for the identification of Trichogramma spp., the laboratory technicians Aurélio Gomes dos Santos (in memoriam) and Cézar Guimarães and the Fundação de Amparo à Pesquisa do Estado de Minas Gerais (FAPEMIG).

\section{REFERENCES}

Bai B, Luck RF, Forster L, Stephens B, Janssen JAM. The effect of host size on quality attributes of the egg parasitoid, Trichogramma pretiosum. Entomol Experiment Appl. 1992; 64 (1): 37-48.

Barrera G, Simon O, Villamizar L, Williams T, Caballero P. Spodoptera frugiperda multiple nucleopolyhedrovirus as a potential biological insecticide: genetic and phenotypic comparison of field isolates from Colombia. Biol Control. 2011; 58: 113-120.

Beserra EB, Parra JRP. Comportamento de parasitismo de Trichogramma atopovirilia Oatman and Platner e Trichogramma pretiosum Riley (Hymenoptera, Trichogrammatidae) em posturas de Spodoptera frugiperda (J. E. Smith) (Lepidoptera, Noctuidae). Rev Bras Entomol. 2003; 47 (2): 205-209.

Beserra EB, Parra JRP. Biologia e parasitismo de Trichogramma atopovirilia Oatman and Platner e Trichogramma pretiosum Riley (Hymenoptera, Trichogrammatidae) em ovos de Spodoptera frugiperda (J.E. Smith) (Lepidoptera, Noctuidae). Rev Bras Entomol. 2004; 48 (1): 119-126. 
Da Fonseca FL, Kovaleski A, Foresti J, Ringenberg R. Desenvolvimento e exigências térmicas de Trichogramma pretiosum Riley (Hymenoptera: Trichogrammatidae) em ovos de Bonagota cranaodes (Meyrick) (Lepidoptera: Tortricidae). Neotrop Entomol. 2005; 34 (6): 945-949.

Doyon J, Boivin G. The effect of development time on the fitness of female Trichogramma evanescens. $J$ Insect Sci. 2005; 5 (4): 1-5.

Dutton A, Bigler F. Flight activity assessment of the egg parasitoid Trichogramma brassicae (Hym.: Trichogrammatidae) in laboratory and field conditions. Entomophaga. 1995; 40 (2): 223-233.

Gomes JM. SAEG 3.0: sistema de análises estatísticas e genéticas. Viçosa: Imprensa Universitária; 1985.

Gonring AHR, Picanco MC, Zanuncio JC, Puiatti M, Semeão AA. Natural biological control and key mortality factors of the pickleworm, Diaphania nitidalis Stoll (Lepidoptera: Pyralidae), in cucumber. Biol Agric Hortic. 2003; 20: 365-380.

Hoballah ME, Degen T, Bergvinson D, Savidan A, Tamo C, Turlings TCJ. Occurrence and direct control potential of parasitoids and predators of the fall armyworm (Lepidoptera: Noctuidae) on maize in the subtropical lowlands of Mexico. Agr Forest Entomol. 2004; 6 (1): 83-88.

Hohmann CL, Luck RF. Effect of host availability and egg load in Trichogramma platneri Nagarkatti (Hymenoptera: Trichogrammatidae) and its consequences on progeny quality. Braz Arch Biol Technol. 2004; 47 (3): 413-422.

Inoue MSR, Parra JRP. Efeito da temperatura no parasitismo de Trichogramma pretiosum Riley, 1879 sobre ovos de Sitotroga cerealella (Olivier, 1819). Sci Agri. 1998; 55 (2): 227-232.

Lundgren JG, Heimpel GE. Quality assessment of three species of commercially produced Trichogramma and the first report of thelytoky in commercially produced Trichogramma. Biol Control. 2003; 26 (1): 68-73.

Miranda MMM, Picanço M, Zanuncio JC, Guedes RNC. Ecological life table of Tuta absoluta (Meyrick) (Lepidoptera: Gelechiidae). Biocontrol Sci Techn. 1998; 8 (4): 597-606.

Navarro RV, Marcano R. Tablas de vida de Trichogramma pretiosum Riley y $T$. atopovirilia Oatman y Platner en el laboratorio. Agr Trop. 2000; 50 (1): 123-134.

Neto FDC, Cruz I, Zanuncio JC, Silva CHO, Picanço MC. Parasitism by Campoletis flavicincta on Spodoptera frugiperda in corn. Pesq Agropec Bras. 2004; 39 (11): 1077-1081.

Neto FCM, Zanuncio JC, Cruz I, Guedes RNC, Picanço MC. Progeny prodution and parasitism by Campoletis flavicincta (Hym.: Ichneumonidae) as affected by female ageing. Biol Agric Hort. 2005; 22 (4): 369378.

Oliveira HN, Zanuncio JC, Pratissoli D, Cruz I. Parasitism rate and viability of Trichogramma maxacalli (Hym.: Trichogrammatidae) parasitoid of the Eucalyptus defoliator Euselasia apison (Lep.: Riodinidae), on eggs of Anagasta kuehniella (Lep.: Pyralidae). Forest Ecol Manage. 2000; 130: 1-6.

Oliveira HN, Zanuncio JC, Pratissoli D, Picanço MC. Biological characteristics of Trichogramma maxacalii (Hymenoptera: Trichogrammatidae) on eggs of Anagasta kuehniella (Lepidoptera: Pyralidae). Braz Arch Biol Technol. 2003; 63 (4): 647-653.

Oztemiz S, Kornosor S. The effects of different irrigation systems on the inundative release of Trichogramma evanescens westwood (Hymenoptera: Trichogrammatidae) against Ostrinia nubilalis Hubner (Lepidoptera: Pyralidae) in the second crop maize. Turk J Agric For. 2007; 31: 23-30.

Parra JRP. Técnicas de criação de Anagasta kuehniella, hospedeiro alternativo para a produção de Trichogramma. In- Trichogramma e o controle aplicado, ed. J.R.P. Parra; R.A. Zucchi. Piracicaba: FEALQ; 1997.

Parra JRP, Zucchi RA. Trichogramma in Brazil: feasibility of use after twenty years of research. Neotrop Entomol. 2004; 33 (3): 271-281.

Pereira FF, Barros R, Pratissoli D, Parra JRP. Biologia e exigências térmicas de Trichogramma pretiosum Riley e T. exiguum Pinto and Platner (Hymenoptera: Trichogrammatidae) criados em ovos de Plutella xylostella (L.) (Lepidoptera: Plutellidae). Neotrop Entomol. 2004; 33 (2): 231-236.

Prasad RP, Roitberg BD, Henderson D. The effect of rearing temperature on flight initiation of Trichogramma sibericum Sorkina at ambient temperatures. Biol Control. 1999; 16 (3): 291-298.

Pratissoli D, Parra JRP. Desenvolvimento e exigências térmicas de Trichogramma pretiosum Riley, criados em duas traças do tomateiro. Pesq Agropec Bras. 2000; 35 (7): 1281-1288.

Pratissoli D, Oliveira HN, Gonçalves JR, Zanuncio JC, Holtz AM. Changes in biological characteristics of Trichogramma pretiosum (Hym.: Trichogrammatidae) reared on eggs of Anagasta kuehniella (Lep.: Pyralidae) for 23 generations. Biocontrol Sci Techn. 2004; 14 (3): 313-319.

Pratissoli D, Zanuncio JC, Vianna UR, Andrade JS, Pinon TBM. Biological characteristics of Trichogramma pretiosum and Trichogramma acacioi (Hym: Trichogrammatidae), parasitoids of the avocado defoliator Nipteria panacea (Lep.: Geometridae), on eggs of Anagasta kuehniella (Lep.: Pyralidae). Braz Arch Biol Technol. 2005a; 48 (1): 713.

Pratissoli D, Zanuncio JC, Vianna UR, Andrade JS, Pinon TBM, Andrade GS. Thermal requirements of Trichogramma pretiosum and Trichogramma acacioi (Hym: Trichogrammatidae), parasitoids of the avocado defoliator Nipteria panacea (Lep: Geometridae), in eggs of two alternative hosts. Braz Arch Biol Technol. 2005b; 48 (4): 523-529. 
Prezotti L, Parra JRP, Vencovsky R, Dias CTS, Cruz I, Chagas MCM. Teste de vôo como critério de avaliação da qualidade de Trichogramma pretiosum Riley (Hymenoptera: Trichogrammatidae): Adaptação de metodologia. Neotrop Entomol. 2002; 31 (3): 411-417.

Rodriguez-del-Bosque LA, Cantu-Almaguer MA, Reyes-Mendez CA. Effect of planting date and hybrid selection on Helicoverpa zea and Spodoptera frugiperda (Lepidoptera: Noctuidae) damage on maize ears in Northeastern Mexico. Southwest Entomol. 2010; 35 (2): 157-164.

Scott AJ, Knott MA. A cluster analysis method for grouping means in the analysis of variance. Biometrics. 1974; 30 (3): 507-512.

Soares MA, Zanuncio TV, Zanuncio JC, Mielke OHH, Serrão JE. Euselasia mys lara (Stichel, 1919) (Lepidoptera: Riodinidae) a potential pest on Eucalyptus in Brazil? J Res Lepid. 2009; 41: 76-83.

Soares MA, Leite GLD, Zanuncio JC, Rocha SL, de Sá VGM, Serrão JE. Flight capacity, parasitism and emergence of five Trichogramma (Hymenoptera: Trichogrammatidae) species from forest areas in Brazil. Phytoparasitica. 2007; 35 (3): 314-318.

Stein CP, Parra JRP. Uso da radiação ultravioleta para inviabilizar ovos de Anagasta kuehniella (Zeller, 1879) visando estudos com Trichogramma. An Soc Entomol Brasil. 1987; 16 (1): 229-234.
Stouthamer R, Breeuwer JAJ, Luck RF, Werren JH. Molecular identification of microorganisms associated with parthenogenesis. Nature. 1993; 361: 66-68.

Ulrichs C, Mewis I. Evaluation of the efficacy of Trichogramma evanescens Westwood (Hym., Trichogrammatidae) inundative releases for the control of Maruca vitrata F. (Lep., Pyralidae). J Appl Entomol. 2004; 128 (6): 426-431.

Zago HB, Pratissoli D, Barros R, Gondim Jr. MGC, Santos Jr. HJG. Capacidade de parasitismo de Trichogramma pratissolii Querino and Zucchi (Hymenoptera: Trichogrammatidae) em hospedeiros alternativos, sob diferentes temperaturas. Neotrop Entomol. 2007; 36 (1): 048-089.

Zanuncio JC, da Silva CA, de Lima ER, Pereira FF, Ramalho FD, Serrão JE. Predation rate of Spodoptera frugiperda (Lepidoptera: Noctuidae) larvae with and without defense by Podisus nigrispinus (Heteroptera: Pentatomidae). Braz Arch Biol Techn. 2008; 51 (1): 121-125. 


\section{PÁGINA EM}

BRANCO 